\title{
PENGARUH PERBANDINGAN TEPUNG KIMPUL (Xanthosoma sagittifolium) DAN PASTA DAUN PEGAGAN (Centella asiatica) TERHADAP KARAKTERISTIK COOKIES
}

The Effect of Comparison Xanthosoma (Xanthosoma sagittifolium) Flour with Centella (Centella asiatica) Leaf Paste on The Characteristics of Cookies

\author{
I Kadek Ariyasa ${ }^{1)}$, Putu Timur Ina ${ }^{2)}$, Ni Made Indri Hapsari Arihantana ${ }^{2)}$ \\ ${ }^{1)}$ Mahasiswa Program Studi Ilmu dan Teknologi Pangan, Fakultas Teknologi Pertanian, Unud \\ ${ }^{2)}$ Dosen Program Studi Ilmu dan Teknologi Pangan, Fakultas Teknologi Pertanian, Unud \\ Kampus Bukit Jimbaran, Badung-Bali
}

\begin{abstract}
This study aims to determine the effect of comparison of Xanthosoma flour with Centella leaf paste to the characteristics of cookies produced and the comparison between Xanthosoma flour with Centella leaf paste that is able to produce cookies with the best characteristics. The experimental design used was Block Randomized Design with treatment factor that is the comparison of Xanthosoma flour and Centella leaf paste consisting of 6 levels: 95\%:5\%; 92\%:8\%; 89\%:11\%; 86\%:14\%; 83\%:17\%; 80\%:20\%. The treatment was repeated 3 times to obtain 18 units of experiment. The data obtained were analyzed by ANOVA and if the treatment had a significant effect on the observed variables then continued with Duncan test. The comparison of Xanthosoma flour with Centella leaf paste affected the content of water, coarse fiber, total chlorophyll, vitamin C, antioxidant activities, texture (hedonic and scoring test), aroma (hedonic test), taste (hedonic test) and overall acceptance (hedonic test) and also had no significant effect on color (hedonic test) of cookies. Comparison of $89 \%$ Xanthosoma flour : $11 \%$ Centella leaf paste had the best characteristics of cookies with content of water $4.41 \%$, coarse fiber $7.21 \%$, total chlorophyll 2.51 $\mathrm{mg} / \mathrm{kg}$, vitamin C $1.54 \mathrm{mg} / \mathrm{g}$, antioxidant activities (based on $I C_{50}$ 's value) $65.61 \%$, the aroma was rather liked, the texture was rather liked and crunchy, the color, taste, and overall acceptance liked.
\end{abstract}

Keywords : Xanthosoma flour, Centella leaf paste, cookies

\section{PENDAHULUAN}

Cookies adalah jenis biskuit yang dibuat dari adonan lunak, berkadar lemak tinggi, relatif renyah dan bila dipatahkan penampang potongannya bertekstur kurang padat (Anon., 1992). Cookies merupakan salah satu jenis olahan pangan yang cukup digemari oleh berbagai kalangan, terutama anak-anak karena rasanya yang manis, gurih dengan tekstur yang renyah.

Cookies merupakan makanan yang terbuat dari terigu dimana Indonesia masih mengimpor gandum yang merupakan bahan dasar terigu dari luar negeri. Selain dikarenakan hal tersebut, terigu memiliki kekurangan karena mengandung gluten sehingga tidak dapat dikonsumsi oleh seluruh kalangan terutama penderita gluten intolerance. Salah satu upaya untuk mengurangi impor bahan baku terigu sekaligus meningkatkan keanekaragman pangan adalah dengan cara mengoptimalkan potensi komoditas lokal seperti umbi-umbian. Umbiumbian merupakan salah satu alternatif yang dapat digunakan sebagai makanan pokok bebas gluten dan mudah didapatkan di Indonesia tanpa harus mengimpor dari luar

*Korespondensi Penulis:

Email: ariyasa.ikadek@ gmail.com ${ }^{1}$ 
negeri. Kimpul (Xanthosoma sagittifolium) merupakan salah satu jenis umbi-umbian yang perlu dikembangkan untuk menghasilkan berbagai produk pangan sehingga potensial untuk menggantikan terigu dikarenakan memiliki karbohidrat yang cukup tinggi yaitu sebesar 28,66\%. Menurut Nuraini dan Yuwono (2014), tepung kimpul dapat dimanfaatkan menjadi cookies dan menghasilkan karakteristik fisik, kimia dan uji sensoris terbaik dengan perbandingan tepung kimpul dan tapioka sebanyak 60\%:40\% serta penambahan margarin sebanyak $70 \%$. Cookies yang beredar masih memiliki kekurangan baik dari segi antioksidan, serat, serta vitamin.

Sumber antioksidan, serat, dan vitamin dapat diperoleh salah satunya dari sayursayuran. Salah satu sayuran yang merupakan sumber antioksidan, serat, dan vitamin adalah daun pegagan. Pemanfaatan daun pegagan untuk olahan produk pangan masih sedikit ditemukan. Khusus di Bali, daun pegagan dimanfaatkan sebagai loloh atau minuman herbal yang dipercaya dapat meningkatkan nafsu makan, selain itu pegagan hanya dimanfaatkan sebagai pakan ternak. Daun pegagan merupakan salah satu tanaman yang cukup potensial untuk mengatasi kekurangan antioksidan, dikarenakan dalam daun pegagan mengandung total klorofil sebesar 831,5 $\mathrm{mg} / \mathrm{kg}$ (Nurdin et al., 2009). Daun pegagan memiliki kandungan serat kasar sebesar 14,69\% (Kabaruddin dalam Siregar et al., 2017) serta vitamin C sebesar $0,98 \mathrm{mg} / \mathrm{g}$ (Rukmiasih dalam Mustikarani, 2015).

Berdasarkan hal diatas maka dilakukan penelitian perbandingan tepung kimpul dan pasta daun pegagan sehingga dihasilkan produk olahan pangan berupa cookies yang bergizi dan baik dikonsumsi oleh berbagai kalangan termasuk penderita gluten intolerance karena bebas dari kandungan gluten, selain itu adanya kandungan vitamin $\mathrm{C}$, antioksidan, dan serat yang cukup tinggi pada cookies dapat menjadikan produk ini sebagai pangan fungsional.

\section{METODE PENELITIAN}

\section{Tempat dan Waktu}

Penelitian ini dilaksanakan di Laboratorium Pengolahan Pangan, Laboratorium Analisis Pangan, Laboratorium Biokimia dan Nutrisi, Program Studi Ilmu dan Teknologi Pangan, serta Laboratorium Rekayasa Proses dan Pengendalian Mutu, Program Studi Teknologi Industri Pertanian, Fakultas Teknologi Pertanian, Universitas Udayana. Waktu pelaksanaan mulai bulan Maret sampai dengan bulan Mei 2018.

\section{Bahan dan Alat}

Bahan-bahan yang digunakan dalam melaksanakan penelitian ini terdiri dari bahan baku, bahan tambahan, dan bahan kimia. Bahan baku terdiri dari daun pegagan yang masih hijau, tidak keriput, dan tidak dimakan ulat yang didapat di Desa Guwang, Sukawati, serta kimpul didapat di Desa Suter, Kintamani. Bahan tambahan terdiri dari telur, baking powder dan margarin merk blueband yang diperoleh di toko Fenny. Bahan kimia yang digunakan dalam melakukan analisis meliputi $\mathrm{H}_{2} \mathrm{SO}_{4}, \mathrm{NaOH}$, alkohol 96\%, aquadest, aseton, methanol, 1,1-difenil-2-pikrilhidrazil (DPPH), asam sulfat, sodium fosfat, ammonium molibdat.

Alat yang digunakan untuk membuat cookies adalah mixer (elektrolux) pisau, talenan, sutil, sendok, gunting, waskom, panci, blender (Philips), rolling pan, timbangan digital (ACIS), gelas ukur (Pyrex), cetakan, kompor gas (Rinnai), oven (Sense) dan loyang. Alat yang digunakan untuk analisis sifat fisik dan kimia adalah lumpang, kertas saring, kertas whatman 42, corong, eksikator, botol timbang, oven (Memmert), timbangan analitik (Shimadzu), aluminium foil (Klin Pak), pinset, pipet tetes, pipet volume (Pyrex), kompor listrik, labu erlenmeyer (Pyrex), gelas beaker (Pyrex), gelas ukur (Pyrex), pompa karet, labu takar (Pyrex), tabung reaksi (Pyrex), water bath (thermology), 
spektrofotometer (Thermo), perangkat komputer dan lembar quisioner.

\section{Rancangan Percobaan}

Rancangan yang digunakan pada penelitian ini adalah Rancangan Acak Kelompok (RAK) dengan perlakuan perbandingan tepung kimpul dan pasta daun pegagan yang tedriri dari 6 perlakuan, yaitu :

$\mathrm{P} 1=95 \%$ tepung kimpul : $5 \%$ pasta pegagan $\mathrm{P} 2=92 \%$ tepung kimpul $: 8 \%$ pasta pegagan $\mathrm{P} 3=89 \%$ tepung kimpul : $11 \%$ pasta pegagan $\mathrm{P} 4=86 \%$ tepung kimpul : $14 \%$ pasta pegagan $\mathrm{P} 5=83 \%$ tepung kimpul : $17 \%$ pasta pegagan P6 $=80 \%$ tepung kimpul : $20 \%$ pasta pegagan

Masing-masing perlakuan diulang sebanyak 3 kali sehingga diperoleh 18 unit percobaan. Data yang diperoleh dianalisis dengan sidik ragam dan apabila perlakuan berpengaruh terhadap variabel yang diamati maka dilanjutkan dengan uji Duncan (Gomez dan Gomez, 1995). Perlakuan terbaik diperoleh dari analisis sifat kimia dan evaluasi sifat sensoris cookies.

\section{Pelaksanaan Penelitian}

Bahan-bahan yang digunakan dalam pembuatan cookies yaitu tepung kimpul, pasta daun pegagan, kuning telur, gula bubuk, margarin dan baking powder ditimbang sesuai formula. Adapun formula pembuatan cookies kimpul dapat dilihat pada Tabel 1.

Tabel 1. Formula cookies

\begin{tabular}{|c|c|c|c|c|c|c|}
\hline \multirow{2}{*}{ Komposisi } & \multicolumn{6}{|c|}{ Perlakuan } \\
\hline & $\mathrm{P} 1$ & $\mathrm{P} 2$ & P3 & $\mathrm{P} 4$ & P5 & P6 \\
\hline Tepung kimpul (\%) & 95 & 92 & 89 & 86 & 83 & 80 \\
\hline Pasta daun pegagan $(\%)$ & 5 & 8 & 11 & 14 & 17 & 20 \\
\hline Margarin $(\%)$ & 20 & 20 & 20 & 20 & 20 & 20 \\
\hline Gula halus (\%) & 60 & 60 & 60 & 60 & 60 & 60 \\
\hline Kuning telur (\%) & 50 & 50 & 50 & 50 & 50 & 50 \\
\hline Baking powder $(\%)$ & 1 & 1 & 1 & 1 & 1 & 1 \\
\hline
\end{tabular}

Keterangan : \% bahan-bahan diatas berdasarkan jumlah tepung kimpul dan pasta daun pegagan (100 g).

Tahapan pembuatan cookies kimpul terdiri dari 3 tahap. Tahapan 1 pembuatan tepung kimpul. Kulit umbi segar dikupas lalu dicuci hingga bersih. Kimpul kemudian diiris dengan ketebalan $\pm 1-2 \mathrm{~mm}$ dan direndam dalam larutan garam $2 \%$ selama 2 jam. Ditiriskan, setelah itu dilakukan pengeringan dalam oven pada suhu $60^{\circ} \mathrm{C}$ selama 18 jam. setelah kering kemudian digiling dan diayak dengan ayakan 60 mesh, maka diperoleh tepung kimpul.

Tahapan 2 pembuatan pasta daun pegagan. Daun pegagan disortasi dan dicuci dengan air mengalir. Setelah dicuci daun pegagan kemudian diblansing (dengan metode steam) pada suhu $60^{\circ} \mathrm{C}$ selama 3 menit. Daun pegagan yang telah diblansing tersebut kemudian dihancurkan dengan menggunakan blender, maka diperoleh pasta daun pegagan.
Tahap 3 pembuatan cookies kimpul. Sesuai dengan formula pada Tabel 1, gula bubuk dan margarin dicampur menggunakan mixer selama 2 menit selanjutnya dimasukkan kuning telur dan dicampur menggunakan mixer selama 2 menit, setelah itu dimasukan tepung kimpul dan pasta daun pegagan sesuai perlakuan, serta baking powder kemudian dicampur menggunakan mixer selama 2 menit hingga membentuk adonan cookies. Adonan cookies digiling menggunakan roolpan dan dicetak menggunakan cetakan cookies. Adonan yang telah dicetak diletakan pada loyang yang telah diolesi margarin setelah itu adonan dipanggang didalam oven dengan suhu $180^{\circ} \mathrm{C}$ selama 20 menit, maka dihasilkan cookies. 


\section{Variabel yang Diamati}

Variabel yang diamati dalam penelitian ini meliputi analisis kadar air, kadar serat kasar (Sudarmadji et al., 1997), total klorofil (Nollet, 2004), aktivitas antioksidan (Sompong et al., 2011), dan kadar vitamin C (Vuong et al., 2014). Serta uji sensoris menggunakan uji hedonik terhadap warna, tekstur, aroma, rasa, penerimaan keseluruhan, dan uji skoring terhadap teksur (Soekarto, 1985).

\section{HASIL DAN PEMBAHASAN}

Hasil analisis kadar air, kadar serat kasar, total klorofil, vitamin $\mathrm{C}$, aktivitas antiosidan dari tepung kimpul dan pasta daun pegagan yang digunakan dapat dilihat pada Tabel 2 .

Tabel 2. Nilai rata-rata kadar air, kadar serat kasar, total klorofil, vitamin C, aktivitas antiosidan dari tepung kimpul dan pasta daun pegagan.

\begin{tabular}{lcc}
\hline \multicolumn{1}{c}{ Komponen } & Tepung Kimpul & Pasta Daun Pegagan \\
\hline Air (\%) & 5,57 & 86,52 \\
Serat Kasar $(\%)$ & 1,38 & 4,00 \\
Total Klorofil $(\mathrm{mg} / \mathrm{kg})$ & 0 & 198,43 \\
Vitamin C $(\mathrm{mg} / \mathrm{g})$ & 0,81 & 2,52 \\
Aktivitas Antiosidan $(\%)$ & 190,95 & 33,59 \\
\hline
\end{tabular}

Tepung kimpul dari hasil penelitian memiliki kadar air 5,57\%, kadar serat kasar $1,38 \%$, total klorofil $0 \mathrm{mg} / \mathrm{kg}$, vitamin C 0,81 mg/g, dan aktivitas antioksidan 190,95\%, sedangkan pasta daun pegagan memiliki kadar air $86,52 \%$, kadar serat kasar 4,00\%, total klorofil 198,43mg/kg, vitamin C 2,52mg/g, dan aktivitas antioksidan $33,59 \%$.

Hasil analisis kadar air, kadar serat kasar, total klorofil, kadar vitamin $\mathrm{C}$, dan aktivitas antioksidan cookies dapat pada Tabel 3.

Tabel 3. Nilai rata-rata kadar air, kadar serat kasar, kadar klorofil, kadar vitamin C, dan aktivitas antioksidan cookies

\begin{tabular}{cccccc}
\hline Perlakuan & $\begin{array}{c}\text { Kadar Air } \\
(\%)\end{array}$ & $\begin{array}{c}\text { Kadar Serat Kasar } \\
(\%)\end{array}$ & $\begin{array}{c}\text { Total Klorofil } \\
(\mathrm{mg} / \mathrm{kg})\end{array}$ & $\begin{array}{c}\text { Kadar Vitamin C } \\
(\mathrm{mg} / \mathrm{g})\end{array}$ & $\begin{array}{c}\text { Aktivitas Antioksidan } \\
(\%)\end{array}$ \\
\hline P1 & $3,31 \pm 0,07 \mathrm{~d}$ & $5,60 \pm 0,17 \mathrm{f}$ & $1,50 \pm 0,05 \mathrm{f}$ & $1,22 \pm 0,03 \mathrm{f}$ & $77,22 \pm 0,64 \mathrm{a}$ \\
P2 & $3,74 \pm 0,16 \mathrm{c}$ & $6,09 \pm 0,08 \mathrm{e}$ & $1,81 \pm 0,09 \mathrm{e}$ & $1,34 \pm 0,04 \mathrm{e}$ & $71,82 \pm 0,92 \mathrm{~b}$ \\
P3 & $4,41 \pm 0,16 \mathrm{~b}$ & $7,21 \pm 0,17 \mathrm{~d}$ & $2,51 \pm 0,05 \mathrm{~d}$ & $1,54 \pm 0,03 \mathrm{~d}$ & $65,61 \pm 0,78 \mathrm{c}$ \\
P4 & $4,49 \pm 0,08 \mathrm{~b}$ & $8,79 \pm 0,36 \mathrm{c}$ & $3,37 \pm 0,10 \mathrm{c}$ & $1,68 \pm 0,03 \mathrm{c}$ & $56,05 \pm 0,58 \mathrm{~d}$ \\
P5 & $4,72 \pm 0,11 \mathrm{a}$ & $11,00 \pm 0,23 \mathrm{~b}$ & $3,87 \pm 0,07 \mathrm{~b}$ & $1,85 \pm 0,03 \mathrm{~b}$ & $48,53 \pm 0,98 \mathrm{e}$ \\
P6 & $4,85 \pm 0,11 \mathrm{a}$ & $13,31 \pm 0,23 \mathrm{a}$ & $4,41 \pm 0,17 \mathrm{a}$ & $2,01 \pm 0,02 \mathrm{a}$ & $42,53 \pm 0,96 \mathrm{f}$ \\
\hline
\end{tabular}

Keterangan : Nilai rata - rata yang diikuti oleh huruf yang berbeda pada kolom yang sama menunjukkan perlakuan yang berbeda nyata pada Uji Duncan 0,05 .

\section{Kadar air}

Berdasarkan data hasil sidik ragam dapat dilihat bahwa perbandingan tepung kimpul dan pasta daun pegagan berpengaruh sangat nyata $(\mathrm{P}<0,01)$ terhadap kadar air dari cookies. Kadar air cookies berkisar antara 3,31\% sampai dengan 4,85\%. Kadar air cookies tertinggi diperoleh dari cookies pada perlakuan
P6 (80\% tepung kimpul dan $20 \%$ pasta daun pegagan) yaitu sebesar $4,85 \%$ dan tidak berbeda nyata dengan perlakuan P5, sedangkan kadar air cookies terendah diperoleh dari cookies pada perlakuan P1 (95 $\%$ tepung kimpul dan $5 \%$ pasta daun pegagan) yaitu 3,31\% (Tabel 3).

Cookies dengan formula penambahan pasta 
daun pegagan yang semakin meningkat menghasilkan cookies dengan kadar air yang semakin tinggi. Hal ini disebabkan karena kadar air pada pasta daun pegagan cukup tinggi yaitu sebesar , 86,52\%, sedangkan kadar air dari tepung kimpul adalah 5,57\% (Tabel 2). Kadar air maksimal yang diperbolehkan berdasarkan standar mutu cookies adalah 5\% bb (Anon., 1992), jadi kadar air cookies yang dihasilkan telah memenuhi standar mutu cookies berdasarkan Standar Nasional Indonesia.

\section{Kadar Serat Kasar}

Berdasarkan hasil sidik ragam menunjukan bahwa perbandingan tepung kimpul dan pasta daun pegagan berpengaruh sangat nyata $(\mathrm{P}<0,01)$ terhadap kadar serat kasar cookies. Tabel 3 menunjukan kadar serat kasar cookies yang dihasilkan berkisar antara 5,60\% sampai dengan 13,31\%. Kadar serat kasar cookies tertinggi diperoleh dari cookies pada perlakuan P6 (80\% tepung kimpul dan 20\% pasta daun pegagan) yaitu sebesar $13,31 \%$, sedangkan kadar serat kasar cookies terendah diperoleh dari cookies pada perlakuan P1 (95\% tepung kimpul dan $5 \%$ pasta daun pegagan) yaitu 5,60\% (Tabel 3).

Pembuatan cookies dengan penambahan pasta daun pegagan yang semakin meningkat mengkasilkan cookies dengan kadar serat kasar yang semakin tinggi. Hal ini disebabkan karena kadar serat pasta daun pegagan lebih tinggi dibandingkan tepung kimpul. Berdasarkan analisis bahan baku (Tabel 2) kadar serat kasar pasta daun pegagan adalah $4,00 \%$, sedangkan kadar serat pada tepung kimpul adalah 1,38\%. Standar Nasional Indonesia untuk kadar serat kasar pada cookies adalah $0,5 \%$ sehingga kadar serat hasil penelitian tidak memenuhi syarat SNI dikarenakan kadar serat kasar pada hasil penelitian berkisar antara 5,60\%-13,31\%.

\section{Total Klorofil}

Berdasarkan data dari hasil sidik ragam menunjukan bahwa perbandingan tepung kimpul dan pasta daun pegagan berpengaruh sangat nyata $(\mathrm{P}<0,01)$ terhadap total klorofil cookies. Tabel 3 menunjukan bahwa total klorofil berkisar $1,50 \mathrm{mg} / \mathrm{kg}$ sampai dengan $4,41 \mathrm{mg} / \mathrm{kg}$. Total klorofil cookies tertinggi diperoleh dari cookies pada perlakuan P6 (80\% tepung kimpul dan $20 \%$ pasta daun pegagan) yaitu sebesar $4,41 \mathrm{mg} / \mathrm{kg}$, sedangkan total klorofil cookies terendah diperoleh dari cookies pada perlakuan P1 (95\% tepung kimpul dan $5 \%$ pasta daun pegagan) yaitu 1,50 $\mathrm{mg} / \mathrm{kg}$ (Tabel 3).

Pembuatan cookies dengan penambahan pasta daun pegagan yang semakin meningkat menghasilkan cookies dengan total klorofil yang semakin tinggi. Hal ini disebabkan total klorofil pasta daun pegagan lebih tinggi dibandingkan total klorofil tepung kimpul. Berdasarkan analisis bahan baku (Tabel 2) total klorofil pasta daun pegagan adalah $198,43 \mathrm{mg} / \mathrm{kg}$, sedangkan total klorofil tepung kimpul adalah $0 \mathrm{mg} / \mathrm{kg}$.

\section{Kadar Vitamin C}

Berdasarkan data hasil sidik ragam menunjukkan bahwa perbandingan tepung kimpul dan pasta daun pegagan berpengaruh sangat nyata $(\mathrm{P}<0,01)$ terhadap kadar vitamin $\mathrm{C}$ cookies. Tabel 3 menunjukkan bahwa kadar vitamin C pada cookies berkisar $1,22 \mathrm{mg} / \mathrm{g}$ sampai dengan $2,01 \mathrm{mg} / \mathrm{g}$. Kadar vitamin C cookies tertinggi diperoleh dari cookies pada perlakuan P6 (80\% tepung kimpul dan 20\% pasta daun pegagan) yaitu sebesar $2,01 \mathrm{mg} / \mathrm{g}$, sedangkan kadar vitamin $\mathrm{C}$ cookies terendah diperoleh dari cookies pada perlakuan P1 (95 $\%$ tepung kimpul dan 5\% pasta daun pegagan) yaitu $1,22 \mathrm{mg} / \mathrm{g}$ (Tabel 3 ).

Pembuatan cookies dengan penambahan pasta daun pegagan yang semakin meningkat akan menghasilkan cookies dengan vitamin $\mathrm{C}$ yang semakin tinggi. Hal ini disebabkan tingginya vitamin $\mathrm{C}$ yang terdapat pada pasta daun pegagan yaitu sebesar $2,52 \mathrm{mg} / \mathrm{g}$ berdasarkan hasil analisis bahan baku pada 
Tabel 2, sedangkan kadar vitamin C pada tepung kimpul yaitu $0,85 \mathrm{mg} / \mathrm{g}$. Semakin tinggi konsentrasi pasta daun pegagan menyebabkan kadar vitamin $\mathrm{C}$ pada cookies meningkat.

\section{Aktivitas Antioksidan \\ Berdasarkan data hasil sidik ragam menunjukkan bahwa perbandingan tepung kimpul dan pasta daun pegagan berpengaruh sangat nyata $(\mathrm{P}<0,01)$ terhadap aktivitas antioksidan cookies. Tabel 3 menunjukkan bahwa aktivitas antioksidan pada cookies berdasarkan nilai $\mathrm{IC}_{50}$ berkisar $42,53 \%$ sampai dengan $77,22 \%$. Nilai IC 50 cookies tertinggi diperoleh dari cookies pada perlakuan P1 (95 $\%$ tepung kimpul dan 5\% pasta daun pegagan) yaitu sebesar $77,22 \%$, sedangkan nilai $\mathrm{IC}_{50}$ cookies terendah diperoleh dari cookies pada perlakuan P6 (80\% tepung kimpul dan $20 \%$ pasta daun pegagan) yaitu 42,53\% (Tabel 3).}

Menurut Amanda (2009) Semakin kecil nilai $\mathrm{IC}_{50}$ berarti semakin tinggi aktivitas antioksidan. Semakin tinggi konsentrasi penambahan pasta daun pegagan pada pembuatan cookies menyebabkan nilai $\mathrm{IC}_{50}$ semakin berkurang yang berarti bahwa kemampuan aktivitas antioksidan yang semakin meningkat. Hal ini dikarenakan nilai $\mathrm{IC}_{50}$ dari pasta daun pegagan sebesar $33,59 \%$ (Tabel 2) sedangkan nilai IC $_{50}$ pada tepung kimpul 190,95\%.

\section{Evaluasi Sifat Sensoris}

Evaluasi sifat sensoris cookies dilakukan dengan uji hedonik terhadap warna, tekstur, aroma, rasa dan penerimaan keseluruhan. Uji skoring dilakukan terhadap tekstur cookies. Nilai rata-rata uji hedonik terhadap warna, tekstur, aroma, rasa dan penerimaan keseluruhan cookies dapat dilihat pada Tabel 4. Nilai rata-rata uji skoring terhadap tekstur dapat dilihat pada pada Tabel 5.

Tabel 4. Nilai rata-rata uji hedonik warna, aroma, tekstur, rasa dan penerimaan keseluruhan cookies

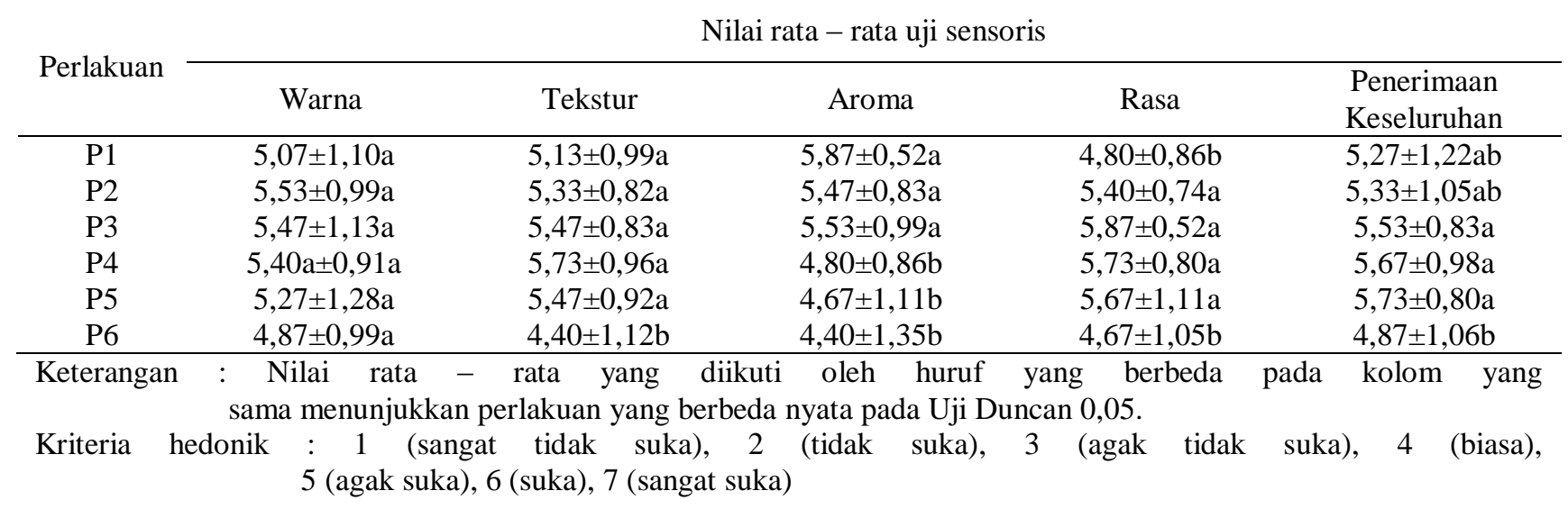

Tabel 5. Nilai rata-rata uji skoring tekstur cookies

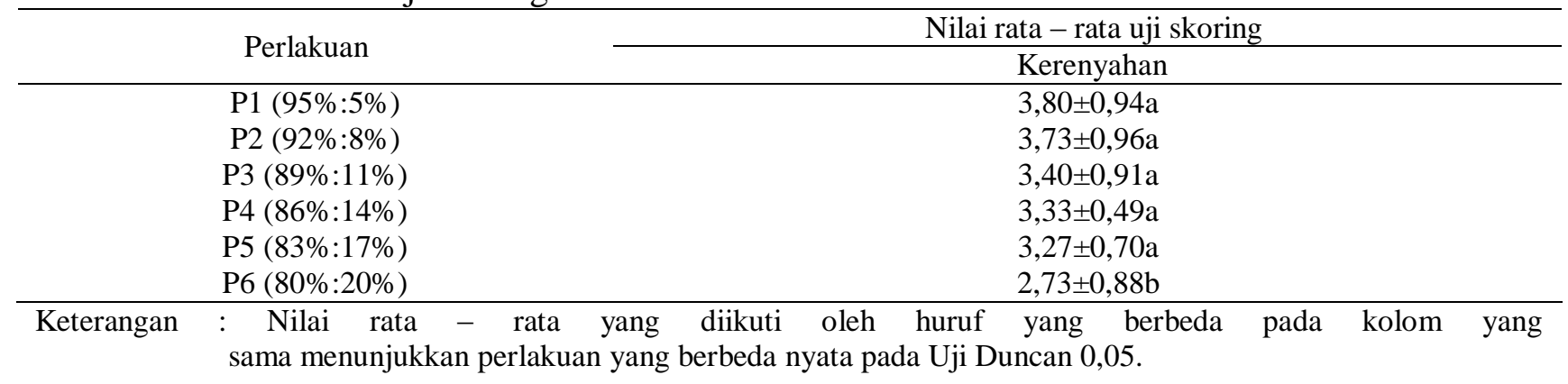


Nilai skoring tekstur : 1 (tidak renyah); 2 (agak renyah); 3 (renyah) ; 4 (sangat renyah); 5 (amat sangat renyah).

\section{Warna}

Berdasarkan data hasil sidik ragam menunjukkan bahwa perbandingan tepung kimpul dan pasta daun pegagan berpengaruh tidak nyata $(\mathrm{P}>0,05)$ terhadap kesukaan warna cookies (Tabel 4). Penerimaan panelis terhadap warna cookies adalah dengan kriteria suka.

Winarno (2004) menyatakan bahwa warna merupakan komponen yang sangat penting untuk menentukan kualitas atau derajat penerimaan suatu bahan pangan. Suatu bahan pangan meskipun dinilai enak dan teksturnya sangat baik, tetapi memiliki warna yang tidak menarik atau memberi kesan telah menyimpang dari warna yang seharusnya maka bahan tersebut tidak akan dikonsumsi. Penentuan mutu suatu bahan pangan pada umumnya tergantung pada warna karena warna tampil terlebih dahulu.

\section{Tekstur}

Berdasarkan data hasil sidik ragam menunjukkan bahwa perbandingan tepung kimpul dan pasta daun pegagan berpengaruh sangat nyata $(\mathrm{P}<0,01)$ terhadap kesukaan tekstur cookies. Nilai rata-rata tingkat kesukaan panelis terhadap tekstur tertinggi diperoleh dari cookies pada perlakuan P4 (86\% tepung kimpul dan $14 \%$ pasta daun pegagan) yaitu dengan kriteria suka dan tidak berbeda dengan perlakuan P1, P2, P3, dan P5 sedangkan nilai rata-rata terendah diperoleh dari cookies pada perlakuan P6 (80\% tepung kimpul dan $20 \%$ pasta daun pegagan) yaitu dengan kriteria biasa (Tabel 4).

Berdasarkan data hasil sidik ragam menunjukkan bahwa perbandingan tepung kimpul dan pasta daun pegagan berpengaruh sangat nyata $(\mathrm{P}<0,01)$ terhadap tekstur (uji skor) cookies. Nilai rata-rata skor tertinggi terhadap tekstur cookies diperoleh pada perlakuan P1 (95\% tepung kimpul dan 5\% pasta daun pegagan) yaitu dengan kriteria sangat renyah dan tidak berbeda dengan perlakuan P2, P3, P4, dan P5 sedangkan nilai rata-rata terendah cookies diperoleh pada perlakuan P6 (80\% tepung kimpul dan 20\% pasta daun pegagan) yaitu dengan kriteria renyah (Tabel 5). Cookies pada umumnya memiliki tekstur yang renyah, mudah dipatahkan, serta memiliki penampang yang berrongga ketika dipatahkan.

\section{Aroma}

Berdasarkan data hasil sidik ragam menunjukkan bahwa perbandingan tepung kimpul dan pasta daun pegagan berpengaruh sangat nyata $(\mathrm{P}<0,01)$ terhadap kesukaan aroma cookies. Nilai rata-rata tingkat kesukaan panelis terhadap aroma tertinggi diperoleh dari cookies pada perlakuan P1 $(95 \%$ tepung kimpul dan $5 \%$ pasta daun pegagan) yaitu dengan kriteria suka dan tidak berbeda dengan perlakuan P2 dan P3 sedangkan nilai rata-rata terendah diperoleh dari cookies pada perlakuan P6 (80\% tepung kimpul dan $20 \%$ pasta daun pegagan) yaitu dengan kriteria biasa dan tidak berbeda dengan perlakuan P4 dan P5.

Meilgaard et al. (2000) menyatakan bahwa aroma makanan timbul disebabkan oleh terbentuknya senyawa volatil yang mudah menguap. Peningkatan konsentrasi penambahan pasta daun pegagan sangat berpengaruh terhadap aroma cookies yang dihasilkan. Hal ini disebabkan karena daun pegagan memiliki aroma khas yang sangat jarang ditemui pada cookies sehingga menyebabkan panelis masih awam dan tidak terbiasa dengan adanya aroma tersebut.

\section{Rasa}

Berdasarkan data hasil sidik ragam menunjukkan bahwa perbandingan tepung kimpul dengan pasta daun pegagan berpengaruh sangat nyata $(\mathrm{P}>0,01)$ terhadap kesukaan rasa cookies. Nilai rata-rata tingkat kesukaan panelis terhadap rasa tertinggi 
diperoleh dari cookies pada perlakuan P3 (89\% tepung kimpul dan $11 \%$ pasta daun pegagan) yaitu dengan kriteria suka dan tidak berbeda dengan perlakuan P2, P4 dan P5 sedangkan nilai rata-rata terendah diperoleh pada perlakuan P6 (80\% tepung kimpul dan 20\% pasta daun pegagan) yaitu dengan kriteria agak suka dan tidak berbeda dengan perlakuan P1 (Tabel 4).

Khasanah (2003) menyatakan bahwa rasa timbul karena rangsangan kimiawi yang dapat diterima oleh indera pencicip atau lidah dan merupakan faktor yang dinilai panelis setelah warna, tekstur, dan aroma yang dapat yang mempengaruhi penerimaan produk pangan. Rasa yang enak dapat menarik perhatian sehingga konsumen lebih cenderung menyukai makanan dari rasanya. Jika komponen aroma, warna dan tekstur baik tetapi konsumen tidak menyukai rasanya maka konsumen tidak akan menerima produk pangan tersebut.

\section{Penerimaan Keseluruhan}

Berdasarkan data hasil sidik ragam menunjukkan bahwa perbandingan tepung kimpul dan pasta daun pegagan berpengaruh nyata $(0,01>\mathrm{P}>0,05)$ terhadap penerimaan keseluruhan cookies. Nilai rata-rata tingkat kesukaan panelis tertinggi terhadap penerimaan keseluruhan dari cookies diperoleh pada perlakuan perlakuan P5 (83\% tepung kimpul dan $17 \%$ pasta daun pegagan) yaitu dengan kriteria suka dan tidak berbeda dengan perlakuan $\mathrm{P} 3$ dan $\mathrm{P} 4$ sedangkan nilai rata-rata terendah diperoleh pada perlakuan P6 (80\% tepung kimpul dan $20 \%$ pasta daun pegagan) yaitu dengan kriteria agak suka (Tabel 5). Penerimaan keseluruhan cookies dipengaruhi oleh beberapa faktor seperti warna, aroma, tekstur dan rasa.

\section{SIMPULAN DAN SARAN}

\section{Simpulan}

Berdasarkan penelitian yang telah dilakukan maka dapat disimpulkan beberapa hal sebagai berikut:

1. Perbandingan tepung kimpul dan pasta daun pegagan berpengaruh terhadap kadar air, kadar serat kasar, vitamin C, total klorofil, aktivitas antioksidan, tekstur (uji hedonik dan skoring), aroma (uji hedonik), rasa (uji hedonik), dan tingkat penerimaan keseluruhan (uji hedonik).

2. Perbandingan $89 \%$ tepung kimpul dengan $11 \%$ pasta daun pegagan menghasilkan cookies dengan karakteristik terbaik yaitu: kadar air $4,41 \%$, kadar serat kasar $7,21 \%$, total klorofil $2,51 \mathrm{mg} / \mathrm{kg}$, kadar vitamin $\mathrm{C}$ $1,54 \mathrm{mg} / \mathrm{g}$, aktivitas antioksidan (berdasarkan nilai $\mathrm{IC}_{50}$ ) 65,61\%, aroma agak disukai, tekstur renyah dan agak disukai, warna, rasa, penerimaan keseluruhan disukai.

\section{Saran}

Berdasarkan hasil penelitian ini disarankan untuk menggunakan perbandingan $89 \%$ tepung kimpul dengan $11 \%$ pasta daun pegagan dalam proses pembuatan cookies.

\section{DAFTAR PUSTAKA}

Amanda, A. 2009. Aktivitas Antioksidan dan Karakteristik Organoleptik Minuman Fungsional Teh Hijau (Camelia sinensis) Rempah Instan. Skripsi Fakultas Pertanian Insitut Pertanian Bogor. Bogor.

Anonimus. 1992. Mutu dan Cara Uji Biskuit (SNI 01- 2973-1992). Badan Standarisasi Nasional. Jakarta.

Gomez, K. A. dan A. A. Gomez. 1995. Prosedur Statistik Untuk Penelitian Pertanian. UI Press. Jakarta

Khasanah, U. 2003. Formulasi Karakterisasi Fisiko-Kimia dan Organoleptik Produk Makanan Sarapan Ubi Jalar (Sweet 
Potato Flakes). Skripsi. Tidak dipublikasi . Fakultas Teknologi Pertanian. Institut Pertanian Bogor, Bogor.

Meilgaard, M., G. V. Civille dan B. T. Carr. 2000. Sensory Evaluation Techniques. Boca Raton. CRC Press. Florida.

Mustikarani, W. 2015. Pengaruh Kombinasi Ekstrak Daun Pegagan (Centella asiatica) dan Daun Beluntas (Plucea indica (L) Less) terhadap Kadar Enzim Transaminase dan Gambaran Histologi Hepar Tikus Putih (Ratus norvegicus) Betina. Skripsi. Tidak dipublikasikan. Fakultas Sains dan Teknologi Universitas Islam Negeri Maulana Malik Ibrahim, Malang

Nollet, LML. 2004. Handbook of Food Analysis. Physical Characterzati-ion and Nutrient Analysis. Marcel Dekker. Inc. 1(2). New York

Nuraini, S. dan S. S. Yuwono. 2014. Pemanfaatan Tepung Kimpul (Xanthosoma sagittifolium) sebagai Bahan Baku Cookies (Kajian Proporsi Tepung Dan Penambahan Margarin). Jurnal Pangan dan Agroindustri Vol.2 No.2

Nurdin., C. M. Kusharto., I. Tanziha, dan M. Januwati. 2009. Kandungan Klorofil Berbagai Jenis Daun Tanaman dan $\mathrm{Cu}-$ Turunan Klorofil Serta Karakteristik Fisiko-Kimianya. Jurnal Gizi dan Pangan. Vol. 4. No. 1

Siregar, R.A.S., A. Nurmi, dan M. Hasibuan. 2017. Pemberian Ekstrak Pegagan (Centella asiatica) Terhadap Performans Ayam Broiler. Jurnal Peternakan Vol. 01 No. 02
Soekarto, S.T. 1985. Penilaian Organoleptik Untuk Industri Pangan dan Pertanian. Bharata Karya Aksara. Jakarta.

Sompong, R., S. S. Ehn, G. L. Martin, dan E. Berghofer. 2011. Physichemical and Antioxidative Properties of Red and Black Rice Varieties from Thailand, China, and Sri Lanka. Food Chemistry 124: $132-140$

Sudarmadji, S. B. Haryono dan Suhardi. 1997. Prosedur Analisa Untuk Bahan Makanan dan Pertanian. Liberty. Yogyakarta

Vuong, Q.V., S. Hirun, T. L. K. Chuen, C. D. Goldsmith, M. C. Bowyer, A. C. Chalmers,P. A. Phillips, dan C. J. Scarlett. 2014. Physicochemical Composition, Antioxidant Andantiproliferative Capacity of a Lilly Pilly (Syzygium paniculatum) Extract. J. Herb. Med. 4, 134-140.

Winarno, F. G. 2004. Hasil-hasil Simposium Penganekaragaman Pangan. Prakarsa Swasta dan Pemda. Jakarta. 